10.15290/cnisk.2019.02.07.08

\author{
DR BEATA GOWORKO-SKŁADANEK \\ orcid.org/0000-0002-8689-1646 \\ Uniwersytet w Białymstoku
}

\title{
Rozwój prasy kobiecej w Rosji do 1917 r.
}

\section{Streszczenie}

W Rosji przed rewolucją na rynku prasy kobiecej dominowały czasopisma o charakterze literacko-społecznym, mające na celu edukację kobiet oraz zapewnienie im rozrywki. Dopiero w okresie rewolucyjnym (1904-1917) wraz z aktywizacją ruchów kobiecych i upolitycznieniem „kwestii kobiecych” nastapił intensywny rozwój prasy kobiecej. Na łamach prasy politycznej feministki i przedstawiciele lewicowych partii politycznych poruszali problemy kobiet związane $z$ ich nierównym statusem $\mathrm{w}$ społeczeństwie i rodzinie. Wzmianki o działalności organizacji kobiecych i prowadzonej walce o prawa kobiet pojawiały się także w czasopismach masowych o charakterze literacko-publicystycznym, w których dominowały jednak tematy związane $z$ prowadzeniem gospodarstwa domowego oraz modą. Propagowały one też często tradycyjną rolę kobiety.

Słowa kluczowe: prasa kobieca, Rosja, czasopisma masowe, prawa kobiet, prasa polityczna

\section{DEVELOPMENT OF WOMEN'S PRESS IN RUSSIA BEFORE 1917}

\begin{abstract}
In Russia, in the pre-revolutionary period, magazines of literary and social character dominated on the female press market, their role was both educating women and providing entertainment to them. In the revolutionary period (1904-1917), the activation of women's movements and the politi-
\end{abstract}


cisation of the "women's issues" affected an intensive development of the women's press. In the political press, feminists and representatives of leftist political parties raised women's problems, their unequal status in society and in the family. In mass magazines of literary and journalistic character, which often promoted the traditional role of women, despite of topics related to running a household and fashion, there were references to the activities of women's organisations and the fight for women's rights.

Keywords: women's press, Russia, mass magazines, women's rights, political press

\section{Wprowadzenie}

Czasopisma poświęcone kobietom pojawiły się w Imperium Rosyjskim później niż w innych krajach europejskich. Powodem tego były nie tylko obiektywne prawa rynku, czyli wysokie koszty zwiazane $z$ ich publikacją, lecz także niezbyt duża odpowiednio przygotowana liczba czytelników, gotowych kupować magazyny kobiece ${ }^{1}$.

Historia prasy kobiecej w Rosji rozpoczęła się w ostatniej ćwierci XVIII w. Jej rozkwit przypada jednak na poczatek XX w., co łączyć należy $z$ postępem naukowym i technologicznym oraz upowszechnianiem edukacji, a co za tym idzie - wzrostem liczby czytelniczek. Pojawiły się też czasopisma masowe, których wydawanie stało się opłacalne, a ich zadaniem było przyciagnięcie jak najszerszej rzeszy czytelniczek. Prasa kobieca obejmowała różne obszary tematyczne, literackie, społeczne i polityczne ${ }^{2}$. Przekazywała głównie informacje, które miały pomóc kobiecie zwrócić uwagę na swój wygląd, prowadzić dom oraz wykonywać domowe prace $^{3}$.

Tematowi prasy kobiecej w piśmiennictwie rosyjskim poświęca się dużo miejsca. Powstało wiele artykułów odnośnie do historii i rozwoju czasopism dedykowanych kobietom. Z uwagi na to, że w Polsce nie znajdziemy zbyt wielu zwartych opracowań na ten temat, celem stało się przybliżenie czytelnikowi zarysu historii rozwoju prasy kobiecej do

\footnotetext{
1 „Damskoje sczastje. O czem pisali żenskije żurnały w carskoj Rossii. FOTO”, [Dostęp: 28.09.2016]. Dostępny w World Wide Web: <https://bit.ly/2ElYHG4>.

2 Wiktorija Wiaczesławowna Smiejucha, „Transformacyja żenskoj priessy w naczale XX w R.G.U.P.S.", Uczenyje zapiski Krymskogo fiedieralnogouniwiersitieta imieni W.I. Wiernadskogo. Fiłołogiczeskije nauki, t. 1, nr 3, 2015, 14, 16-17.

3 Eadem, „Osobiennosti razwitija glancewych żenskich żurnałow”, Wiestnik WGU. Sierija: Fiłołogija. Żurnalistika, nr 1, 2010, 210.
} 
1917 r., czyli okresu, w którym rozwój ten był najintensywniejszy. Ze względu na podjęta tematykę, która nie jest rozpowszechniona w polskim piśmiennictwie, podstawę niniejszego opracowania stanowia materiały rosyjskojęzyczne, zarówno naukowe, jak i publicystyczne.

\section{Początki prasy kobiecej w Rosji}

Pierwsze kobiece czasopisma pojawiły się w Rosji w końcu XVIII w. Ich czytelniczkami były kobiety $z$ wyższych sfer. Rozwojowi prasy kobiecej w tym okresie przeszkadzało zazwyczaj niewystarczajace wykształcenie większości kobiet, które nauczane były głównie w domach. Dopiero za panowania Katarzyny II po raz pierwszy rząd zainteresował się ich edukacją ${ }^{4}$. Cesarzowa przyczyniła się do awansu kobiet, dając im możliwość uczenia się. Jej plany obejmowały tworzenie nowych instytucji edukacyjnych ${ }^{5}$, ale przyjęte rozwiązania i środki nie wpłynęły znacząco na zwiększenie liczby wykształconych kobiet.

Pierwszy magazyn kobiecy pojawił się w 1779 r. w Sankt Petersburgu. Była to „Modna comiesięczna publikacja, czyli biblioteczka na damska toaletkę” („Модное ежемесячное издание, или Библиотека для дамского туалета"), a jego założycielem był Nikołaj Iwanowicz Nowikow, rosyjski pedagog, publicysta, wydawca ${ }^{6}$, którego należy uznać za „ojca” pierwszego w Rosji specjalistycznego czasopisma skierowanego do kobiet ${ }^{7}$. W jego zamyśle miało ono nie tylko zapewniać czytelniczkom rozrywkę, lecz także je edukować ${ }^{8}$. Pojawiały się w nim „teksty literackie do łatwego czytania" - w większości tłumaczone moralizatorskie przypowieści, pouczające wiersze, jak też epigramy, szarady, zagadki i „najcie-

\footnotetext{
4 Eadem, „Razwitije otieczestwiennoj żenskojpriessy w konce XVIII pierwoj połowinie XIX wiekow”, Fiłołogiczeskij wiestnik Rostowskogo uniwiersitieta, nr 1, 1998, 64-65.

5 Lubow' Witaljewna Prudnikowa, „Żurnał «Magazin anglijskich, francuzskich i niemieckich nowych mod.... W.I. Okorokowa”, Wiestnik Moskowskogo uniwiersitieta, Sierija 10. Żurnalistika, nr 4, 2012, 125.

6 „Nowikow Nikołaj Iwanowicz”, Bolszajarossijskaja Encykłopiedija (BRE), [Dostęp: 2.05.2018]. Dostępny w World Wide Web: <https://bit.ly/2rNV74X>.

7 Łesia Wasiljewna Sokolskaja, „Pierwyjeżenskije żurnały dla rossijskich czitatielnic (koniec xviii. pierwaja połowina xix wieka)", BIBLIOSFIERA, nr 2, 2006, 19.

8 Wiktorija Wiaczesławowna Smiejucha, „Razwitije otieczestwiennoj żenskojpriessy”, 64.
} 
kawsze fakty z życia" ${ }^{\prime}$. Był to zabawny magazyn literacki, w którym nie było ilustracji ${ }^{10}$. Magazyn był wydawany przez rok.

Następna próba wydania czasopisma dla kobiet o podobnej tematyce została podjęta zaledwie 12 lat później. Twórcy „Sklepu $z$ angielskimi, francuskimi i niemieckimi nowinkami modowymi” („Магазина английских, французских и немецких новых мод”) wzięli pod uwage błędy poprzednika i postanowili uprościć publikację. Na jej łamach pojawiły się zdjęcia, przyjemne anegdoty oraz opisy rozrywek towarzyszących mieszkańcom najznakomitszych miast ówczesnej Europy ${ }^{11}$. Artykuły o modzie przeplatały się $z$ nowelami literackimi ${ }^{12}$. Redaktor Władymir Okorokow umieszczał w czasopiśmie utwory poetyckie o niezbyt wysokim poziomie artystycznym, ponieważ liczył na niezbyt wyrafinowanych czytelników ${ }^{13}$. Dopełnieniem modnej edycji były recenzje spektakli, wskazówki, które miejsca należało odwiedzić, oraz najświeższe trendy w modzie, prosto $z$ Paryża ${ }^{14}$.

W 1823 r. ukazał się pierwszy numer „Magazynu dla pañ”, którego wydawcą był Pietr Iwanowicz Szalikow, ksiązęe, pisarz i dziennikarz ${ }^{15}$. $Z$ założenia magazyn ten miał zastapić „kosztowne wyciagi z zagranicy”, czyli publikacje będace przedrukiem zagranicznych czasopism. Publikacja miała trzy sekcje: literacka, krytyczną i modna ${ }^{16}$. Autorzy magazynu na jego łamach chwalili kobiety i obsypywali je komplementami. Pojawiały się w nim artykuły mówiace o wpływie kobiet na rozwój społeczeństwa oraz ich znaczacej roli ${ }^{17}$. „Magazyn dla pan”” był wydawany ponad 10 lat.

Na początku czasopisma dla kobiet były tworzone wyłacznie przez mężczyzn. Dopiero w końcu 1836 r. Elizawieta Frantsewna Safonowa

\footnotetext{
9 „Damskoje sczastje”.

10 Tim Iljasow, „Istorija żurnałow mod w Rossii. Czast' 1. Ot Pietrowskoj Assamblei do riewolucyi w Pietrogra", Materiality.info, [Dostęp: 1.09.2017]. Dostępny w World Wide Web: https://materiality.info/2017/01/09/magazine-story/.

11 Lubow' Witaljewna Prudnikowa, „Żurnał "Magazin anglijskich, francuzskich i niemieckich nowych mod"”, 125.

12 Ibidem, 126.

13 Ibidem, 130.

14 Tim Iljasow, „Istorija żurnałow mod w Rossii”.

15 „Szalikow Pietr Iwanowicz”, [Dostęp: 4.05.2018]. Dostępny w World Wide Web: http:// www.rulex.ru/01250281.htm.

${ }^{16}$ "O czom pisali żenskije żurnałyproszłych wiekow”, [Dostęp: 8.11.2017]. Dostępny w World Wide Web: http://www.izbrannoe.com/news / eto-interesno/o-chyem-pisali-zhenskie-zhurnaly-proshlykh-vekov/.

17 Marija Sołowjowa, „Czemu uczili żenskije żurnały proszłych wiekow”, Kultura.RF, [Dostęp: 7.07.2018]. Dostępny w World Wide Web: <https://bit.ly/2PGEW1q>.
} 
rozpoczęła wydawanie „Najnowszego magazynu o szyciu” („Журнал новейшего шитья"). Całe swoje życie poświęciła czasopismom dla kobiet, które wydawała i redagowała. W latach 60. XX w. Safonowa prowadziła legendarny magazyn „Waza” ${ }^{18}$.

Opisane powyżej czasopisma, określane mianem literacko-społecznych, skierowane były do szerokiego grona czytelników, o niskim wykształceniu i niskich dochodach. Głównymi odbiorcami miały być kobiety - matki, żony, kochanki, pracownice. Na łamach periodyków opisywane były praktyczne porady odnośnie do prowadzenia gospodarstwa domowego, rozwiazywania problemów małżeńskich, wykonywania robótek ręcznych, pojawiały się artykuły o modzie, kosmetykach, pielęgnacji ciała, praktyczne wskazówki na temat edukacji, leczenia i profilaktyki chorób u dzieci i dorosłych. $Z$ uwagi na przyjętą różnorodność tematyczną czasopisma te miały charakter uniwersalny. Zaznaczyć należy, że wpływ na ich treść miała także zmieniająca się sytuacja społeczno-polityczna w Rosji. Ukazywały się one w formacie cotygodniowym, dwutygodniowym lub comiesięcznym ${ }^{19}$.

Pierwsze czasopisma kobiece $z$ okresu przedrewolucyjnego to:

- „Modna comiesięczna publikacja, czyli biblioteczka na damska toaletkę” („Модное ежемесячное издание, или Библиотека дмя дамского туалета", 1779),

- „Sklep z angielskimi, francuskimi i niemieckimi nowinkami modowymi” („Магазина английских, французских и немецких новых мод”, 1791),

- „Żurnal dla pięknych, publikowany przez młodych ludzi” („Журнал для милых, издаваемый молодыми мюдьми", 1804),

- „Aglaja” („Аглая”, 1808-1812),

- „Świat kobiet” („Женский мир”, 1811),

- „Gabinet Aspazii” („Кабинет Аспазии”, 1815),

- „Zwiastun mody” („Модный вестник”, 1816),

- „Uniwersalny magazyn mody” („Всеобщий модный журналь”, 1817),

- „Magazyn dla pań” („Дамский журнал”, 1823-1883),

- „Waza” („Ваза”, 1832-1848; w kolejnych latach czasopismo wielokrotnie zmieniało nazwę),

18 Tim Iljasow, „Istorija żurnałow mod w Rossii”.

19 „Istorija żenskich żurnałow w Rossii: żurnalnajapieriodika naczała XX wieka”, [Dostęp:

3.12.2013]. Dostępny w World Wide Web: <https://bit.ly/2PNiLXk>.. 
- „Najnowszy magazyn o szyciu” („Журнал новейшего шитья”, 18361837),

- „Luczi” („Аучи”, 1850-1860),

- „Świt” („Рассвет”, 1859-1862),

- „Jaskółka” (Аасточка”, 1859; w połowie 1860 r. przekształcona w „Bukiet” [„Букет”]),

- „Modne światło” / „Modne światło i modny sklep” („Модный свет” / „Модный свет и модный магазин”, 1868-1916),

- „Przyjaciel kobiety” („Друг женщины”, 1882-1884),

- „Magazyn o modzie” („Ве́стник мо́ды”, 1885-1918),

- „Modny kurier. Wydanie rodzinne” (Модный курьер. Издание дмя семьи", 1899-1915).

\section{Okres rewolucyjny (1905-1907 i 1917)}

Poczatek XX w. to czas aktywizacji ruchów kobiecych, włączenia kobiet do walki politycznej i rosnące znaczenie prasy politycznej ${ }^{20}$. W rosyjskiej prasie kobiecej z tego okresu poruszano problemy kobiet zwiąane $z$ ich nierównym statusem $w$ społeczeństwie i rodzinie. Na te tematy na łamach prasy feministycznej wypowiadały się przede wszystkim feministki i przedstawiciele lewicowych partii politycznych ${ }^{21}$. Publikacje o charakterze politycznym, „Dziennik kobiecy” („Женский вестник”22, 1904-1917) i „Zwiazek (unia) kobiet” („Союз женщин”, 1907-1909), opowiadały się za przyznaniem kobietom praw obywatelskich i politycznych, które odzwierciedlały idee krajowego ruchu feministycznego ${ }^{23}$.

Czasopismo „Женский вестник” założone zostało w 1904 r. przez lekarkę Mariję Iwanowną Pokrowskają, jedną z pierwszych aktywistek rosyjskiego ruchu feministycznego, publicystkę ${ }^{24}$, która twierdziła, że w Rosji nie ma czasopisma zajmującego się wyłącznie kwestią kobiecą.

\footnotetext{
${ }^{20}$ Wiktorija Wiaczesławowna Smiejucha, „Transformacyja żenskoj priessy”, 16.

21 Jekatierina Iwanowna Gusiewa, Tatjana Wiktorowna Jerszowa, „Żenskaja bolszewistskaja priessa w 1914-1917 gody", Wiestnik Moskowskogo gorodskogo piedagogiczeskogo uniwiersitieta. Sierija: Istoriczeskije nauki, nr 2(26), 2017, 35.

22 Słowo „вестник” zawarte w nazwie wydawanych periodyków tłumaczone jest jako „wiadomości” lub „dziennik”. Jan Wawrzyńczyk (red.), Wielki słownik rosyjsko-polski, (Warszawa : PWN, 2015), 134.

${ }^{23}$ Wiktorija Wiaczesławowna Smiejucha, „Transformacyja żenskoj priessy”, 16.

24 „Pokrowskaja Marija Iwanowna”, Bolszajarossijskaja Encykłopiedija (BRE), [Dostęp:

2.05.2018]. Dostępny w World Wide Web: <https://bit.ly/2RVE3Vp>.
} 
„Podczas gdy w rękach kobiet nie znajdują się gazety czy czasopisma, którymi moga zarządzać samodzielnie i niezależnie od mężczyzn, nie moga powiedzieć wszystkiego, co chciałyby powiedzieć o sobie, a tym bardziej o mężczyznach"25. Periodyk pierwotnie miał charakter społeczno-naukowo-literacki i poruszał kwestie kobiece. Chciał poprawić pozycje kobiet w edukacji, aktywności zawodowej, zwracał uwagę na przypadki dyskryminacji w społeczeństwie i rodzinie $z$ uwagi na płeć $^{26}$. Ponieważ „kobiety i żeńska młodzież, które sa świadome nieprawidłowości w obecnym systemie, maja prawo do oświecenia, do wiedzy, do niezależności w pracy, starania się walczyć $z$ ignorancja" ${ }^{27}$. Wydanie różniło się od masowych czasopism kobiecych, przeważały w nim tematy publiczne ${ }^{28}$.

W 1905 r. powstał Związek Równouprawnienia Kobiet (Союз Равноправности женщин). Organizacja ta była jednym $z$ największych ruchów feministycznych w Rosji i dawała swoim członkom możliwość zdobycia bezcennych doświadczeń w działaniach organizacyjnych, propagandowych, społecznych i politycznych. Jednym $z$ jej najważniejszych zadań było promowanie idei równości kobiet. $Z$ uwagi na obojętność opinii publicznej i prasy na działalność Związku działacze i przywódcy na jednym $z$ kongresów postanowili ustanowić ad hoc komitet redakcyjny odpowiedzialny „za publikację książek i broszur na temat problemów kobiet i kwestii wyjaśnienia programu politycznego Zwiąku". Wydawnictwo postawiło następujące cele do zrealizowania: idea równych praw dla kobiet w umysłach mas; kształcenie młodszego pokolenia „w duchu i świetle tej idei”; wskazanie dróg prowadzacych do realizacji tego pomysłu; wspieranie kobiet walczących o równość. Oprócz „książek i broszur” przywódcy Związku zdecydowali się opublikować własny magazyn poświęcony wyłącznie kwestii kobiet. Na bazie tych doświadczeń w 1907 r. ukazał się pierwszy numer magazynu „Zwiazek kobiet”29.

\footnotetext{
25 Susanna Wiaczesławowna Kradieckaja, „Żenskij wiestnik» (1904-1917). Opyt izdanija fieministskogo żurnała w Rossii”, Żenszczina $w$ rossijskom obszczestwie, nr 1, 2013, 72. ${ }^{26}$ Larisa Wołodimiriwna Fiłipienko, „Żurnał "Żenskij wiestnik» (1904-1917) ta "Sojuz żenszczin" (1907-1909) jak nowij tip "idiejnich" żinoczich widan”, Naukowi studii. Istoricznij archiw, nr 9, 2012, 136.

27 Marija Iwanowna Pokrowskaja, „Wozrażenije riecenzientu "Russkoj mysli»”, Żenskij wiestnik, nr 3, 1905, 86-87.

28 „Pokrowskaja Marija Iwanowna”, Bolszajarossijskaja Encykłopiedija (BRE), [Dostęp: 2.05.2018]. Dostępny w World Wide Web: <https://bit.ly/2RVE3Vp>.

29 Susanna Wiaczesławowna Kradieckaja, „Żurnał "Sojuz żenszczin” (1907-1909 gg.). Istorija izdanija i osnownyje osobiennosti”, Wiestnik piermskogo uniwiersitieta, Wypusk 3(20), 2012, 56.
} 
Początkowo żadna $z$ partii politycznych nie wydawała odrębnej publikacji skierowanej do kobiet pracujacych, walczacych o swoje prawa, na łamach której mogłaby prowadzić propagandę i agitację partyjną. Wynikało to $z$ tego, że bolszewicy nie wyodrębniali kwestii kobiecej z ogólnych zadań klasy robotniczej i byli zdecydowanie przeciwni istnieniu niezależnych organizacji kobiecych, ponieważ wierzyli, że walka kobiet $\mathrm{w}$ ramach ruchu robotniczego będzie skuteczniejsza niż w ramach ruchów feministycznych ${ }^{30}$. Sytuacja uległa zmianie wraz ze zwiększeniem aktywności pracujących kobiet ${ }^{31}$, głównie w branżach tekstylnej, odzieżowej i obuwniczej, które coraz częściej brały udział w antyrządowych wiecach, strajkach, demonstracjach ${ }^{32}$. Dostrzeżona została potrzeba stworzenia środków masowego przekazu, w których byłaby prowadzona propaganda skierowana do żeńskiego audytorium. Włodzimierz Iljicz Lenin wysuną ideę utworzenia specjalnego magazynu kobiecego, wokół którego mogłyby się zjednoczyć pracujące kobiety ${ }^{33}$, w którym propagowane byłyby poglądy ruchu kobiecego ze szczególnym uwzględnieniem interesów kobiecego ruchu robotniczego ${ }^{34}$. Idea ta została przekształcona w czasopismo „Rabotnica” („Работница”), które powstało z inicjatywy RSDLP (РСДРП - Российская социал-демократическая рабочая партия) promującego zaangażowanie kobiet w walkę proletariatu ${ }^{35}$. Program realizowany na jego łamach został zdefiniowany przez Nadieżdę Krupska w następujących sekcjach tematycznych: Od redakcji - obecna polityka; Ruch robotniczy i uczestnictwo w różnych jego aspektach (spółdzielnie polityczne i gospodarcze); Warunki pracy w fabrykach, za lada, w warsztatach, w przemyśle; Ochrona pracy kobiet; Kronika niewolnika; Dział Międzynarodowy (walka kobiet-robotników); Rodzina i robotnica ${ }^{36}$.

30 Jekatierina Iwanowna Gusiewa, Tatjana Wiktorowna Jerszowa, „Żenskaja bolszewistskaja priessa", 35.

31 Beata Goworko-Składanek, „Obchody międzynarodowego dnia kobiet w Rosji w latach 1913-1991", Czasopismo Naukowe Instytutu Studiów Kobiecych, nr 2(3), 2017, 61-62.

32 Irina Wiktorowna Ałfierowa, „Bolszewistskaja żenskaja pieczat: $\mathrm{k}$ istorii stanowlenija (1914-1920-je gg)”, Istoriczeskije, fiłosofskije, politiczeskije i juridiczeskije nauki, kulturołogija $i$ iskusstwowiedienije. Woprosy tieorii i praktyki, Tambow: Gramota, nr 6(12), cz. 3, 2011, 18.

33 Jekatierina Iwanowna Gusiewa, Tatjana Wiktorowna Jerszowa, „Żenskaja bolszewistskaja Pressa", 36.

34 "O żurnale "Rabotnica»", [Dostęp: 2.05.2018]. Dostępny w World Wide Web: https:// rabotnitsa.su/.

35 Wiktorija Wiaczesławowna Smiejucha, „Transformacyja żenskoj priessy”, 16.

36 Jekatierina Iwanowna Gusiewa, Tatjana Wiktorowna Jerszowa, „Żenskaja bolszewistskaja Pressa", 36. 
Pierwszy numer „Robotnicy” opublikowany został w Międzynarodowy Dzień Kobiet 23 lutego (8 marca) w 1914 r., redakcja zaś w nim napisała, że:

Niedawno w Rosji kwestia organizacji pracownic stała się jedna $z$ najbardziej palących kwestii ... pracownica została wciagnięta w walkę, która prowadzi klasa robotnicza o swoje prawa ... Dziennik „Robotnica" chce przyjść im z pomoca. Ma wyjaśniać nieświadomym kobietom ich interesy. Będzie wskazywać, że łącza je wspólne interesy ze wszystkimi robotnikami, z cała klasa robotnicza, nie tylko Rosji, ale wszystkich krajów. „Robotnica” opowie o tym, jak pracownicy współpracuja, aby walczyć o swoje prawa ${ }^{37}$.

Poza kobiecymi pismami o tematyce społeczno-politycznej z okresu rewolucyjnego, które zostały przedstawione powyżej, pojawiały się w tym czasie także czasopisma zawierające treści odnoszące się do mody, haftu, prowadzenia gospodarstwa domowego, zaprojektowane dla masowego odbiorcy. Zaliczyć do nich należy periodyki ${ }^{38}$ :

- „Kobieta” („Женщина”, 1907-1917),

- „Damski świat” („Дамский мир”, 1907-1917),

- „Myśl kobieca” („Женская мысль”, 1909-1910),

- „Biznes dla kobiet” („Женское демо”, 1910-1918),

- „Czasopismo dla gospodyń domowych” („Журнал для хозяек”, 19121926),

- „Świat kobiety” („Мир женщины”, 1912-1917),

- „Czasopismo dla kobiet” („Журнал дмя женщин”, 1914-1918),

- „Życie kobiet” („Женская жизнь”, 1914-1916).

$\mathrm{Na}$ łamach masowych czasopism o charakterze literacko-publicystycznym umieszczane były przeważnie kroniki ruchu kobiecego oraz wzmianki o działalności organizacji kobiecych. Pomimo aprobaty działalności feministek, zmierzającej do uzyskania przez kobiety praw i wol-

\footnotetext{
37 „В последнее время у нас в России вопрос об организации работниц стал одним из самых насущных вопросов ... работница втянута в ту борьбу, которую ведет рабочий класс за свои права ... Журнал "Работница" хочет прийти ей на помощь. Он будет выяснять малосознательным работницам их интересы. Будет указывать на то, что интересы у них общие со всеми рабочими, со всем рабочим классом не только России, но и всех стран. "Работница" будет рассказывать о том, как объединяются рабочие повсюду дмя борьбы за свои права". Żurnat Rabotnica, 23.02.1914, nr 1, 1.

38 „Żenskaja priessa w Rossii”, [Dostęp: 1.07.2018]. Dostępny w World Wide Web: $<$ https://bit.ly/2PIYO45>.
} 


\section{Strona tytułowa pierwszego numeru czasopisma „Rabotnica”}

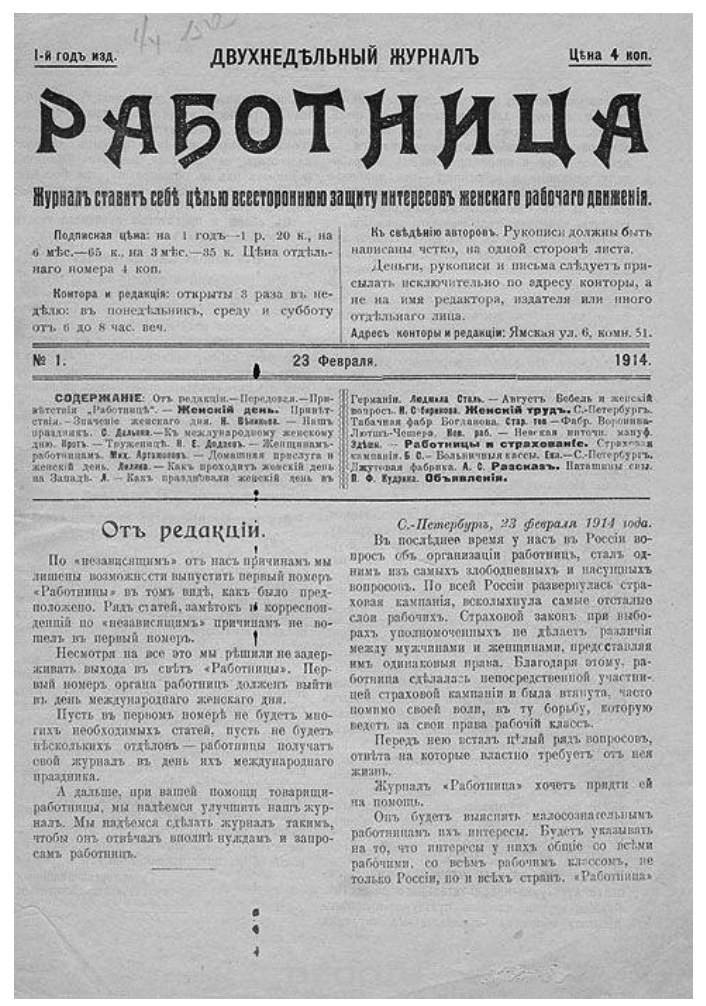

Źródło: Żurnał „Rabotnica”, 23.02.1914, nr 1, 1.

ności obywatelskich, autorzy masowych pism kobiecych nie w pełni popierali idee feministyczne. Za to na łamach czasopism modowych często propagowana była tradycyjna rola kobiety ${ }^{39}$.

W okresie rewolucyjnym ukazywały się następujące żurnale modowe ${ }^{40}$ :

- „Wort” („Ворт”, 1905-1913),

- „Domowa krawcowa” („Домашняя портниха”, 1906-1908), zamieniony później na „Damskie bogactwo” („Женское богатство”, 19081909),

- „Paryżanka” („Парижанка”, 1908-1910),

- „Swiat kobiet” („Женский мир”, 1909-1911),

- „Modny kurier” („Модный курьер”, Petersburg 1900-1910),

39 Wiktorija Wiaczesławowna Smiejucha, „Transformacyja żenskoj priessy”, 17.

40 „Istorija żenskich żurnałow w Rossii”. 
- „Ilustrowane czasopismo pościeli i robótek ręcznych” („ИА^юстрированный журнал белья и рукоделия”, 1901-1907),

- „Pościel i haft” („Белье и вышивки”, 1909-1916),

- „Moda dla wszystkich” („Моды для всех”, 1910-1914).

Na początku XX w. pojawiła się także prasa studencka dla młodych panien, która ukazywała się w instytucjach edukacyjnych dla kobiet. Czasopisma studenckie obejmowały szeroki zakres tematów, od dziewczęcych do politycznych. Artykułom towarzyszyły czarno-białe ilustracje. Wydawane były następujące tytuły ${ }^{41}$ :

- „Damska szkoła kijowska Wołodkiewicza” („Женское киевское училище Володкевич"),

- „Początek” („Начамо”, 1906-1911),

- „Przebiśnieg” („Подснежник”, 1907-1910, 1912),

- „Kolos” („Колос”, 1908-1910, 1912),

- „Pszczoła” („Пчекка”, 1909-1915),

- „Nasz przyjaciel” („Наш друг”, 1911-1914),

- „Potoczek” („Ручеeк”, 1913-1914),

- „Próbka pióra i atramentu, jaka jest w nich moc” („Проба пера и черника, яка в них сима", 1916),

- „Orzeł” („Оряе” [Первые шаги], 1911),

- „Kaszyra” („Кашире” [Наш журнала], 1918).

\section{Podsumowanie}

Pierwsze czasopisma kobiece wydawane w Rosji borykały się z najważniejszym problemem, jakim była mała liczba wyedukowanych kobiet, która przekładała się na mała liczbę czytelniczek. Brak wsparcia materialnego, które wynikało $z$ niewielkiej liczby subskrypcji, oraz wysokie koszty druku czy przedruku powodowały, że wydanie danego tytułu ograniczało się często do kilku numerów. Co więcej, na rynku dostępnych było wiele książek dedykowanych kobietom, o podobnej zawartości co pierwsze czasopisma, które miały głównie charakter literacki. To w nich pojawiały się opowiadania, wiersze i fraszki. Miały one nie tylko zapewniać rozrywki czytelniczkom, lecz także popularyzować edukację kobiet ${ }^{42}$.

\footnotetext{
41 Ibidem.

42 Natalja Władimirowna Podworko, Natalija Wasiljewna Isajewa, „Istoriko-tipołogiczeskoje izuczenije żenskoj priessy", Trudy Rostowskogo gosudarstwiennogo uniwiersitieta
} 
Z problemem niewielkiej liczby czytelników borykała się też większość czasopism kobiecych wydawanych na początku XX w. Pojawiły się również inne problemy, zwiazane $z$ charakterem społeczno-politycznym wydawanych czasopism, które w rzeczywistości nie pasowały do tradycyjnej kategorii magazynów kobiecych.

Rynek publikacji kobiecych $z$ okresu rewolucyjnego odzwierciedlał stan społeczeństwa rosyjskiego, w którym tradycyjne pojmowanie roli płci współistniało $z$ rozwijającym się ruchem feministycznym i tworzeniem robotniczych partii politycznych ${ }^{43}$. Podjęta $\mathrm{w}$ tamtym okresie debata publiczna na temat „kwestii kobiecych” miała ogromne znaczenie dla ewolucji prasy kobiecej ${ }^{44}$. Trzeba jednak zaznaczyć, że bardzo ważne sprawy, takie jak walka o prawa polityczne dla kobiet, były omawiane nie tylko na łamach prasy feministycznej.

Należy też podkreślić, że mimo żywej koncepcji tworzenia publikacji politycznych dla kobiet w tym czasie w dalszym ciagu na rynku prasy dominowały czasopisma uniwersalne, na łamach których pojawiały się tradycyjne tematy interesujące czytelników. Dlatego na koniec okresu rewolucyjnego rosyjska prasa kobieca była bardzo zróżnicowana.

\section{Bibliografia}

\section{Opracowania:}

Ałfierowa, Irina Wiktorowna. „Bolszewistskaja żenskaja pieczat’: $\mathrm{k}$ istorii stanowlenija (1914-1920-je gg)", Istoriczeskije, fiłosofskije, politiczeskije i juridiczeskije nauki, kulturołogija $i$ iskusstwowiedienije. Woprosy tieorii i praktyki, Tambow: Gramota, nr 6(12), cz. 3, 2011, 16-23.

Fiłipienko, Łarisa Wołodimiriwna. „Żurnał “Żenskij wiestnik» (1904-1917) ta "Sojuz żenszczin" (1907-1909) jak nowij tip «idiejnich" żinoczich widan”, Naukowi studii. Istoricznij archiw, nr 9, 2012, 135-141.

putiejs oobszczenija, nr 1(30), 2015, 132.

${ }_{43}$ Moskwiczej prigłaszajut na wystawku o roli priessy $w$ riewolucyi 1917 goda, DISTRIPRIESS, [Dostęp: 15.08.2017]. Dostępny w World Wide Web: < https://bit. ly/2soX08i>.

${ }^{44}$ Ksenia Lwowna Mitrochina, „Rossijskije żurnały dla żenskojauditorii w 1859-1862 godach: spiecyfika obraszczenija k obszczestwiennoj tiematikie”, Wiestnik RUDN. Sierija litieraturowiedienije. Żurnalistika, nr 4, 2009, 118. 
Goworko-Składanek, Beata. „Obchody międzynarodowego dnia kobiet w Rosji w latach 1913-1991", Czasopismo Naukowe Instytutu Studiów Kobiecych, nr 2(3), 2017, 58-73.

Gusiewa, Jekatierina Iwanowna, Jerszowa, Tatjana Wiktorowna. „Żenskaja bolszewistskaja priessa w 1914-1917 gody", Wiestnik Moskowskogo gorodskogo piedagogiczeskogo uniwiersitieta. Sierija: Istoriczeskije nauki, nr 2(26), 2017, 35-42.

Kradieckaja, Susanna Wiaczesławowna. „Żenskij wiestnik” (1904-1917). Opyt izdanija fieministskogo żurnała w Rossii”, Żenszczina w rossijskom obszczestwie, nr 1, 2013, 72-81.

Kradieckaja, Susanna Wiaczesławowna. „Żurnał "Sojuz żenszczin” (19071909 gg.). Istorija izdanija i osnownyje osobiennosti”, Wiestnik piermskogo uniwiersitieta, Wypusk 3(20), 2012, 56-61.

Mitrochina, Ksenia Lwowna. „Rossijskije żurnały dla żenskojauditorii w 1859-1862 godach: spiecyfika obraszczenija k obszczestwiennoj tiematikie", Wiestnik RUDN. Sierija litieraturowiedienije. Żurnalistika, $\mathrm{nr} 4$, 2009, 117-123.

Podworko, Natalja Władimirowna, Isajewa, Natalija Wasiljewna. „Istoriko-tipołogiczeskoje izuczenije żenskoj priessy", Trudy Rostowskogo gosudarstwiennogo uniwiersitieta putiejs oobszczenija, nr 1(30), 2015, 130-134.

Pokrowskaja, Marija Iwanowna. „Wozrażenije riecenzientu "Russkoj mysli»”, Żenskij wiestnik, nr 3, 1905, 86-87.

Prudnikowa, Lubow' Witaljewna. „Żurnał «Magazin anglijskich, francuzskich i niemieckich nowych mod..."W.I. Okorokowa", Wiestnik Moskowskogo uniwiersitieta, Sierija 10. Żurnalistika, nr 4, 2012, 125-136.

Smiejucha, Wiktorija Wiaczesławowna. „Osobiennosti razwitija glancewych żenskich żurnałow", Wiestnik WGU. Sierija: Fiłołogija. Żurnalistika, nr 1, 2010, 209-214.

Smiejucha, Wiktorija Wiaczesławowna. „Razwitije otieczestwiennoj żenskojpriessy w konce XVIII pierwoj połowinie XIX wiekow”, Fiłołogiczeskij wiestnik Rostowskogo uniwiersitieta, $\mathrm{nr}$ 1, 1998, 64-67.

Smiejucha, Wiktorija Wiaczesławowna. „Transformacyja żenskoj priessy w naczale XX w R.G.U.P.S.", Uczenyje zapiski Krymskogo fiedieralnogouniwiersitieta imieni W.I. Wiernadskogo. Fiłołogiczeskije nauki, t. 1, nr 3, 2015, 14, 13-22. 
Sokolskaja, Łesia Wasiljewna. „Pierwyjeżenskije żurnały dla rossijskich czitatielnic (koniec xviii. pierwaja połowina xix wieka)", BIBLIOSFIERA, $\mathrm{nr} 2$, 2006, 18-22.

Wawrzyńczyk, Jan (red.). Wielki słownik rosyjsko-polski, (Warszawa : PWN, 2015), 1-937.

Żurnał Rabotnica, 23.02.1914, nr 1.

\section{Publikacje internetowe:}

„Damskoje sczastje. O czem pisali żenskije żurnały w carskoj Rossii. FOTO”, [Dostęp: 28.09.2016]. Dostępny w World Wide Web: <https://bit. ly/2ElYHG4>.

Iljasow, Tim. „Istorija żurnałow mod w Rossii. Czast' 1. Ot Pietrowskoj Assamblei do riewolucyi w Pietrogra", Materiality.info, [Dostęp: 1.09.2017]. Dostępny w World Wide Web: <https://materiality.info/2017/01/09/ magazine-story/>.

„Istorija żenskich żurnałow w Rossii: żurnalnajapieriodika naczała XX wieka", [Dostęp: 3.12.2013]. Dostępny w World Wide Web: <https://bit. ly/2PNiLXk>.

Moskwiczej prigłaszajut na wystawku o roli priessy w riewolucyi 1917 goda, DISTRIPRIESS, [Dostęp: 15.08.2017]. Dostępny w World Wide Web: <https://bit.ly/2soX08i>.

„Nowikow Nikołaj Iwanowicz”, Bolszajarossijskaja Encykłopiedija (BRE), [Dostęp: 2.05.2018]. Dostępny w World Wide Web: <https://bit.ly/2rNV74X>.

„O czom pisali żenskije żurnały proszłych wiekow”, [Dostęp: 8.11.2017]. Dostępny w World Wide Web: http://www.izbrannoe.com/news/eto-interesno/o-chyem-pisali-zhenskie-zhurnaly-proshlykh-vekov/.

”O żurnale "Rabotnica", [Dostęp: 2.05.2018]. Dostępny w World Wide Web: https://rabotnitsa.su/.

„Pokrowskaja Marija Iwanowna”, Bolszajarossijskaja Encykłopiedija (BRE), [Dostęp: 2.05.2018]. Dostępny w World Wide Web: <https://bit. ly/2RVE3Vp>.

Sołowjowa, Marija. „Czemu uczili żenskije żurnały proszłych wiekow”, Kultura.RF, [Dostęp: 7.07.2018]. Dostępny w World Wide Web: <https:// bit.ly/2PGEW1q>. 
„Szalikow Pietr Iwanowicz”, [Dostęp: 4.05.2018]. Dostępny w World Wide Web: http://www.rulex.ru/01250281.htm.

„Żenskaja priessa w Rossii”, [Dostęp: 1.07.2018]. Dostępny w World Wide Web: <https://bit.ly/2PIYO45>. 